tricity in which the light quantum passes completely to matter, that is, the photon is annihilated. As one would expect from the author, wave mechanics is treated with great clearness and thero is no attempt to represent the theory as having resolved all diffi. culties; on the contrary, at each partial success its incomplete nature is commented on and the requirements of a more complete solution are specified.

\section{Egg Storage}

A Descrirriox is given in the Electrical Review of September 15 of the Chelmsford Egg Supply Co. (193.1). This company utilizes a process for the preservation of eggs which, it is claimed, keeps them fresh indefinitely. It is said that, if eggs are frozen below $28^{\circ} \mathrm{F}$. they crack, so that storage by freezing is imprasticable. Storage in gas is better, but it takes time for the gas to percolnte through the shell. The company has, however, overcome this difficulty. Fiery egg has a small air space at the top. 'This increases as the egg ages. By means of a pump tho air is extracted and replaced by carbon dioxido and nitrogen under a pressure of $250 \mathrm{~mm}$., this pressure being maint ained all the time the eggs are in storage. The eggs aro stored in large cylinders each holding 234,000 eggs and are kept at a temperaturo of $30^{\circ} \mathrm{F}$. Ench refrigerating unit is driven by a 6 h.p. motor, and in addition, two extra motors are cmployed, 5 h.p. and $2 \cdot 75$ h.p. respectively, for circulating tho water and ammonia. The gas.tight cylinders in which the eggs aro stored look like large boilers. An additional chamber held at a much lower temperature is used for freezing liquid eggs, that is, those which have been accidently cracked, and aro sold to local bakeries. Tho factory is also a national mark packing station capable of dealing with a million and a half eggs a week. Tho electricity taken per annum from the public supply is nearly 60,000 units. As this load is very nearly constant, and is heaviest during tho summer montlıs, the load factor is excellent and an attractive tariff is available. The seasonal differenco in the price of eggs practically makes up for the cost of storage.

\section{Extensions of Carrier Telephone Systems}

Is the quarterly edition (No. 17) of Nippon Electrical Engincering, published in English by the Institute of Electrical Communication Engineers of Japan, there is an important paper on carrier telephone systems which make use of lighting and power distribution lines. It is written by $\mathbf{N}$. Shinohara, $\mathbf{Y}$. Hirano and M. Yoshioka, and contains many useful experimental and theoretical results. They point out that the economies effected by using existing power and lighting circuits as part of the carrier system make it possible to extend communication to out-of-the-wny districts, as, for example, farming listricts, fishing villages, lighthouses, etc. This will unake possible the rapid cultural development of these places. They consider first of all the use of high-tension distribution lines as part of the carrier frequency transmission circuit. In the past this has been done by two systems; the first is called the metallic circuit system and the second the ground return circuit system. Although the first system oxcels the latter so far as low attenuation and noise are concerned, the second is the system which is moro commonly employed owing to its greater economy and trustworthiness. The authors state that in utilizing the high-tension distribution line it is best to employ the ground return circuit system. Tho most commonly employed types of high-tension systems are the single-phase two-wiro type and the threo-phase three-wiro type. The height of the wires above the ground is not uniform, but, whero the lins is oven, the averago height is about seven metres. By considering a singlo copper wiro $5 \mathrm{~mm}$. in diameter at a height of 7 metres above the ground and at a temperature of $20^{\circ} \mathrm{C}$. and $\Omega$ frequency of $50 \mathrm{kc}$., they compute that the speed of the carrier waves is nearly equal to the speed of light and that the attenuation constant is very small. Thoy concludo by describing a method of designing a circuit by a new telephone system which they state will bo the most suitable for a rural district. They show how much moro economical the new system would be than the one at present in use.

\section{Oceanographical Results from Central America}

In July and August 1938, the President of the United States, the Honorable Franklin D. IRooserelt, undertook un inspection eruise and fishing expedition from San Diego, California, to I'ensazola, Florida, by wny of the Panama Canal, aboard the U.S.S. Houston. Between July 16 and August 9 some 5,888 miles were covered and fourteen different collecting stops wero made, distributed among the possessions of five different nations: Mexico (Lower California and Socorro Island), France (Clipperton Island), Ecuador (tho Galapagos Islands), Costa IRica (Cocos Island), and Colombia (Old Providence Island in the Caribbean). Dr. Waldo L. Schmitt of the United States National Museun accompanied tho expedition as a naturalist. The results are published in a series of papers of which four are before us: "Decapod and Other Crustacea" (with Introduction and Data) (Smithsonian Miscellaneous Collections, 98, No. 6, Pub. 353I) by Waldo I. Schmitt; "Molluscs" (Pub. 3535 ) by Paul Bartsch and Harald Alfred Rehder; "A New Holothurian of the Genus 'Thyone" (Pub. 3537) by Elisabeth Deichmann; and "I'wo New Gobioid Fishes" by Isaac Ginsburg (Pub. 3539), May-June 1939. A number of new species of Mollusca are described, and lists of species given from tho various collecting grounds.

\section{Grass Drying}

A nEPOnT on fodder conservation with special reference to grass drying by F. J. Roberts has been published by the Agricultural Research Council (H.M. Stationery Office. 2s.). This is the third report on the subject, and embodies the results of the most recent experiments carried out with the co-operation of agricultural organizers, colleges and experi. mental farms in Great Britain. A detailed account 